\title{
Total Protein Concentrations and Protein Fractions in Whole Saliva from Healthy Subjects and Edentulous Subjects, Measured by Cellulose Acetate Membrane Electrophoresis and High Sensitivity Silver Staining
}

Yukiko Takahashi $^{1}$; Yukie Shiina ${ }^{1}$; Akihiko Shiba ${ }^{1}$; Hiroaki Tsukazaki ${ }^{1}$; Emiko Kimura ${ }^{1}$; Yoshihiko Marutanii ${ }^{1}$; Kenji Yūki ${ }^{1}$; Kiyoko Shiba'; and Ryo Kubota ${ }^{2}$

${ }^{\prime}$ Removable Prosthodontics, Showa University, and ${ }^{2}$ Graduate School of Allied Health Sciences, Tokyo Medical and Dental University

\begin{abstract}
Whole saliva was collected by a spit out method from 52 dentulous subjects (21 to 31 years old) who had no systemic disease and were diagnosed to have normal periodontium by oral cavity examination and from 11 subjects ( 60 to 85 years old) who were completely edentulous and using complete dentures, and the concentration of total protein and protein fractions in collected whole saliva were measured using cellulose acetate membrane and the silver staining method developed by Shiba et al. Since this silver staining method is highly sensitive, prior concentration of saliva was not needed.

The mean \pm S.D. of the total protein concentrations obtained by dot blotting-silver staining was $1,197.3 \pm 698.5 \mathrm{mg} / \mathrm{l}$ for the group of all dentulous subjects and $2,202.0 \pm 1,625.0 \mathrm{mg} / \mathrm{l}$ for the group of all edentulous subjects, and these values were significantly different $(p$ $<0.05$ ). Sex difference was not significant in either group.

In protein fractionation by means of cellulose acetate membrane electrophoresis, the following 8 protein fractions could be fractionated clearly: (from the anode) albumin, pre- $\alpha_{1}$-globulin, $\alpha_{1}$-globulin, $\alpha_{2}$-globulin, $\beta_{1}$-globulin, $\beta_{2}$-globulin, IgA and $\gamma$-globulin. In all specimens analyzed, IgA and albumin fractions showed sharp peaks. The IgA fraction had the largest percentage area among the 8 protein fractions, which was $36.7 \pm 5.6 \%$ (mean \pm S.D.) in dentulous subjects and $39.0 \pm 4.6 \%$ in edentulous subjects. The albumin and $\beta_{1}$-globulin fractions showed significantly greater percentage areas in dentulous subjects than in edentulous subjects, whereas the percentage area of $\boldsymbol{\gamma}$-globulin fraction was significantly greater in edentulous subjects $(p<0.01)$. The concentration of individual proteins, which was calculated by multiplying the total protein concentration to the percentage fraction. Edentulous subjects showed significantly greater concentrations of IgA and $\gamma$-globulin $(p<0.05)$. No sex difference was observed in the percentage area and the concentration of individual protein fractions in either group. Among salivary proteins, IgA and albumin were identified by immunofixation.

Key Words Whole Salivary Protein Concentration; Whole Salivary Protein Fraction; Silver Staining; Edentulous Subjects; Healthy Subjects
\end{abstract}

\section{INTRODUCTION}

Saliva always lubricates the stomatic environments to make dental occlusion, mastication, swallowing and vocalization smooth, and prevents dental caries and periodontitis from occurring. In addition, the saliva protects intra-oral mucosa ${ }^{[1],[2]}$ and

Received: May 30, 2003.

'Address; Removable Prosthodontics, Showa University, 2-1-1 Kitasenzoku, Ota-ku, Tokyo, 145-8515 Japan. TEL: 81-3-3787-1151, FAX: 81-3-3787-6774, E-mail:

${ }^{2}$ Address; Graduate School of Allied Health Sciences, Tokyo Medical and Dental University, 1-5-45, Yushima, Bunkyo-ku, Tokyo, 113-8519 Japan contributes to the maintenance and stabilization of dentures. ${ }^{[3]-[5]}$ Systemically, salivary enzymes and proteins play such various roles as follows: Chemical digestion by ptyalin, sterilization by salivary enzymes and proteins such as lysozyme, lactoferrin, peroxidase, IgA, IgG and IgM, and growth/development and the prevention of aging by the endocrine action of parotin. It is also the fact that the saliva faithfully reflects systemic diseases and general health conditions, since plasma components are taken up into acinar cells through capillary vessels, and the substances synthesized in acinar cells are secreted together with water into the oral cavity. ${ }^{[6]}$ Moreover, the saliva reflects the status of intra-oral diseases, because the saliva secreted into the oral cavity merges with the crevicular fluid secreted into the oral cavity, and with ablated epithelial cells, bacteria and leukocytes. ${ }^{[7], ~[8]}$ Since the saliva has abundant information for grasping changes in the body as mentioned above, the examination of the constituents of whole saliva was thought to be significant for grasping the conditions of not only oral cavity but also systemic diseases, and several such attempts were made previously. ${ }^{[9]-[11]}$ However, the concentration of individual salivary constituents is small compared with the serum. Thus, practically speaking, it is hard to say that salivary constituents are being utilized widely for clinical diagnosis and analysis.

On the above background, we focused proteins in whole saliva. Since the silver stain, which is the high sensitivity protein staining medium developed by Shiba et al., was preliminarily found to be able to detect salivary proteins and protein fractions without any pre-condensation if their concentrations are $50 \mathrm{mg} / \mathrm{l}$ and more, we combined dot blotting with the silver staining and measured protein concentrations in whole saliva in the present study for the purpose of investigating the difference in salivary protein fractions between the group of dentulous subjects and the group of edentulous subjects. In addition, proteins in whole saliva were fractionated using the combination of cellulose acetate membrane and the silver staining.

\section{MATERIALS AND METHODS}

\section{Materials}

The whole saliva samples analyzed were collected from 52 subjects ( 26 men and 26 women, 21 to 31 years of age) who had complete teeth and no systemic diseases and were confirmed to have normal periodontium by oral cavity examination, and from 11 subjects ( 7 men and 4 women, 60 to 85 years of age) who had no residual teeth and were using complete dentures. 
Judgment of normal periodontium was based on the following criteria: (1) Apparently advanced inflammation is not observed in periodontium by visual observation, (2) when bleeding of probing (BOP) is scored as follows: no bleeding after $\mathrm{BOP}=0$, bleeding occurs $20 \mathrm{sec}$ after $\mathrm{BOP}=1$, bleeding occurs immediately after $\mathrm{BOP}=2$, and spontaneous bleeding is present $=3$, the maximum bleeding score is 1 or less, and the mean bleeding score is 0.2 or less. (3) The maximum depth of periodontal pockets is $3.0 \mathrm{~mm}$ or less, and (4) there is no attachment loss. ${ }^{[12]}$

\section{Collection and pre-treatment of whole saliva}

Whole saliva samples were collected into test tubes during a period from 11:00 to 13:00 by spitting out at a rough rate of $1 \mathrm{ml}$ per 1-2 min. The saliva samples collected were kept in ice or a cooler box with cold insulators, and then centrifuged at 10,000 rpm for $15 \mathrm{~min}$ at $4^{\circ} \mathrm{C}$. The supernatant was dispensed to be about $500 \mu \mathrm{l}$ for each, stored at $-40^{\circ} \mathrm{C}$, and used for experiments within 1 week after collection.

\section{Preparation of the silver stain, and silver staining}

The silver stain was prepared according to the method of Matsuda et al. ${ }^{[13]}$ Briefly, $12 \mathrm{~m} l$ of $0.25 \%$ Tween 20 solution was mixed with $15 \mathrm{ml}$ of $25 \mathrm{mM}$ ferrous sulfate solution, then with 5 $\mathrm{m} l$ of $280 \mathrm{mM}$ sodium citrate solution, by upside-down mixing every time. Then, $1 \mathrm{~m} l$ of $350 \mathrm{mM}$ silver nitrate solution was added and mixed by vigorous shaking, and $2 \mathrm{ml}$ of $15 \%$ acetic acid was added finally and mixed by upside-down turning.

Silver staining was performed as follows: Specimens were soaked in the fixative $(8 \mathrm{mM}$ sulfosalicylic acid and $0.6 \mathrm{M}$ trichloroacetic acid) for $5 \mathrm{~min}$, then in the washing solution (1\% acetic acid) for $5 \mathrm{~min}$ to fix proteins, and then stained for $20 \mathrm{~min}$ with the silver stain prepared immediately before. The specimens were washed with distilled water for $15 \mathrm{~min}$ and soaked for $3 \mathrm{~min}$ in the fixative solution ( $0.1 \mathrm{M}$ sodium bicarbonate: $0.1 \mathrm{M}$ anhydrous sodium carbonate $=5: 1$ ). Excessive moisture on the cellulose acetate membrane was mildly wiped off with a filter paper, and the specimens were dried spontaneously.

\section{Measurement of total protein concentration}

The dot blotting-silver staining method devised by Matsuda et $a l .{ }^{[14]}$ was used for the measurement of total protein concentrations.

The cellulose acetate membrane (Separax SP, Fuji Film, JAPAN), was cut into $7 \mathrm{~cm} \times 10 \mathrm{~cm}$, and each section was partitioned to be $1 \mathrm{~cm} \times 1 \mathrm{~cm}$ to obtain 70 compartments. Three micro-liter of the saliva sample diluted 20 times with physiological saline and $3 \mu l$ of the standard solutions that were the Electrophoresis Control for Serum Protein Normal (Jyoko, JAPAN) prepared to be $25,50,100,200,400$ and $700 \mathrm{mg} / \mathrm{l}$ using physiological saline were spotted at the center of individual compartments and silver-stained for $5 \mathrm{~min}$. After drying, the absorbance at $505 \mathrm{~nm}$ was measured using the densitometer (Shimadzu CS9000 , JAPAN). A calibration curve was prepared from the observed values of absorbance of standard solutions, and protein concentrations in samples were calculated.

\section{Protein fractions}

Using the applicator 10 (Joko, JAPAN), $0.4 \mu \mathrm{l}$ of saliva sample prepared to be $400 \mathrm{mg} / \mathrm{l}$ and the standard solution (Electrophoresis Control for Serum Protein prepared to be $400 \mathrm{mg} / \mathrm{l}$ ) were applied onto a cellulose acetate membrane. Electrophoresis was performed at a constant current of $0.7 \mathrm{~mA} / \mathrm{cm}$ for about 30 min using Veronal buffer solution ( $\mathrm{pH} 8.6$, ionic strength 0.06 ). Immediately

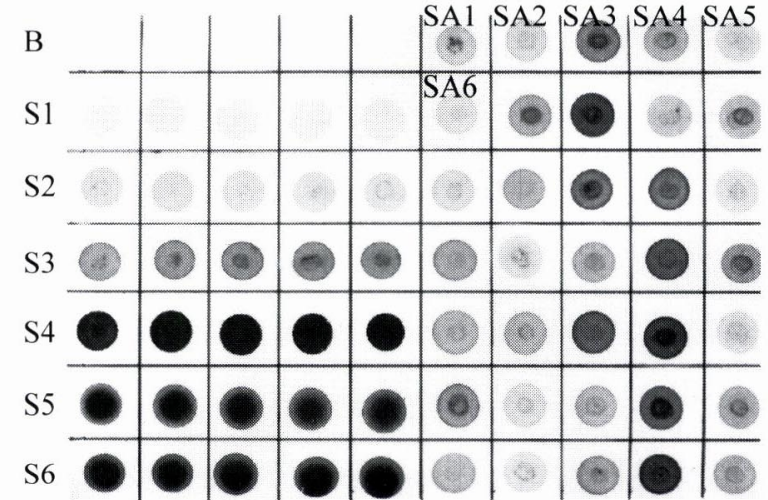

Fig. 1 The measurement of salivary total protein level by dot blottingsilver staining. Standard (B: Physiological saline, S1: $25 \mathrm{mg} / \mathrm{l}$, S2: $50 \mathrm{mg} / l, \mathrm{~S} 3: 100 \mathrm{mg} / \mathrm{l}, \mathrm{S} 4: 200 \mathrm{mg} / \mathrm{l}, \mathrm{S} 5: 400 \mathrm{mg} / \mathrm{l}, \mathrm{S} 6: 700$ $\mathrm{mg} / l$ ), Salivary sample (SA1-SA35)

after electrophoresis, silver staining was conducted for $20 \mathrm{~min}$. After drying, the percentage area of individual proteins was obtained by densitometry (at $505 \mathrm{~nm}$ ) using the densitometer (Cliniscan, Helena Research Institute, USA). Then, the percentage area was multiplied by the total protein concentration to obtain the concentration of each protein fraction.

\section{Immunofixation of protein bands}

Protein bands were identified by means of immunofixation. A cellulose acetate membrane, $13 \mathrm{~cm}$ in width, was electrophoresed conventionally for $30 \mathrm{~min}$, then the cellulose acetate membrane section $(2 \mathrm{~cm} \times 1 \mathrm{~cm})$ to which about $22 \mu l$ of the specific antiserum (DACO, Sweden) had been absorbed was superimposed onto the cellulose acetate membrane to be identified, and left for $20 \mathrm{~min}$ for completing an antigen-antibody reaction. Then, the membrane was deproteinized for $45 \mathrm{~min}$ by physiological saline, and silver staining was conducted for $5 \mathrm{~min}$.

\section{Statistical analysis}

Statistical programs in EXCEL were used for statistical analysis. The $t$-test was used for the intra-group comparison of the sex difference in the group of subjects with complete teeth and the group of edentulous subjects, and for the inter-group comparison of total protein concentrations and protein fractions. When $p<0.05$, the difference was considered statistically significant.

\section{RESULTS}

\section{Total protein concentration}

An example of actual measurement of total protein concentration by dot blotting-silver staining is illustrated in Fig. 1. Standard solutions were stained homogenously and had no problem, whereas many saliva samples remained residues at the center of the site spotted. However, since the periphery of the center was stained homogenously, the absorbance values were measured at 4 spots in the periphery and their mean value was employed. The calibration curve obtained from standard solutions was linear in a concentration range from 25 to $400 \mathrm{mg} / \mathrm{l}$ (Fig. 2), and the lowest detection sensitivity was $2.5 \mathrm{mg} / \mathrm{l}$.

The mean total protein concentration in dentulous subjects was $1,261.6 \pm 703.2 \mathrm{mg} / \mathrm{l}$ (ranged from 251.9 to $3,166.6 \mathrm{mg} / \mathrm{l}$ ) for male subjects and $1,133.0 \pm 701.6 \mathrm{mg} / \mathrm{l}(271.3$ to $3,350.0 \mathrm{mg} / \mathrm{l})$ for female subjects, and no significant difference was noted in sex dif- 


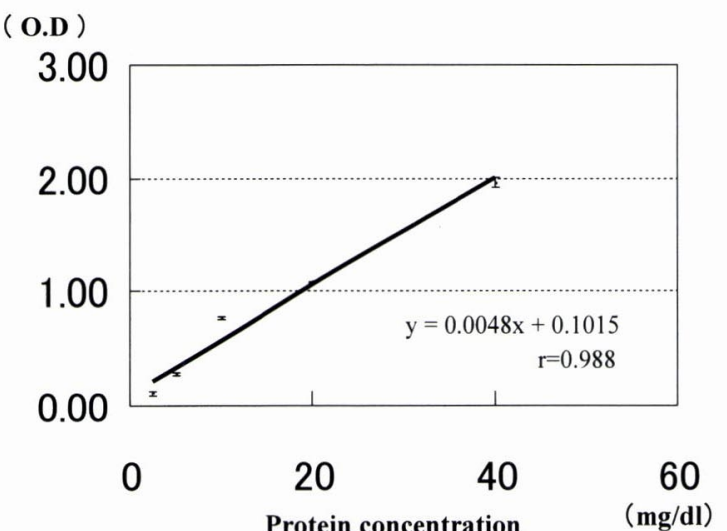

Fig. 2 Typical calibration curve.

Table 1 The concentration of total protein in saliva of dentulous and edentulous subjects.

\begin{tabular}{|c|c|c|c|c|}
\hline \multirow{2}{*}{} & \multicolumn{2}{|c|}{ Dentulous subjects } & \multicolumn{2}{c|}{ Edentulous subjects } \\
\cline { 2 - 5 } & Number & $\mathrm{x} \pm 1 \mathrm{SD}(\mathrm{mg} / l)$ & Number & $\mathrm{x} \pm 1 \mathrm{SD}(\mathrm{mg} / l)$ \\
\hline Male & 26 & $1,261.6 \pm 703.2$ & 7 & $2,170.5 \pm 1718.0$ \\
\hline Female & 26 & $1,133.0 \pm 701.6$ & 4 & $2,257.0 \pm 1701.0$ \\
\hline Total & 52 & $1,197.3 \pm 698.5$ & 11 & $2,202.0 \pm 1625.0 *$ \\
\hline
\end{tabular}

$* p<0.05$ (dentulous subjects vs. edentulous subjects)

ference. The mean total protein concentration in all dentulous subjects was $1,197.3 \pm 698.5 \mathrm{mg} / \mathrm{l}$ (251.9 to $3350.0 \mathrm{mg} /$ ) (Table 1). On the other hand, the mean total protein concentration in all edentulous subjects was $2,202.0 \pm 1,625.0 \mathrm{mg} / \mathrm{l}(1,076.0$ to $6,045.0 \mathrm{mg} / \mathrm{l})$. The mean total protein concentration in all edentulous subjects was significantly higher than that in all dentulous subjects $(p<0.05)$.

\section{Protein fractions}

Owing to the use of silver staining, sharp protein fraction patterns could be obtained without any prior concentration (Fig. 3).

In all specimens from subjects with complete teeth and edentulous subjects, a pre- $\gamma$-globulin (pre- $\gamma$-G) faction was most densely stained and this fraction was identified as an $\operatorname{IgA}$ band by immunofixation. An albumin (Alb) fraction was also observed and this was identified as Alb by immunofixation. Other observed bands were a single band on the anodal side immediately next to the IgA band, very faint two bands each for $\beta$-globulin $(\beta-G)$ and $\alpha_{2}$-globulin $\left(\alpha_{2}-\mathrm{G}\right)$, one band on the anodal side next to the $\alpha_{1}$ globulin $\left(\alpha_{1}-G\right)$ band, and a very weak band on the anodal side immediately next to the Alb band.

When electrophoretic patterns were compared between the group of dentulous subjects and the group of edentulous subjects, the Alb band was wider in dentulous subjects than in edentulous subjects, and a single band tended to be observed on the anodal side of the Alb band in edentulous subjects.

Thus, salivary protein fractions from both subject groups were identified by densitometry. Usually, five fractions are observed for serum proteins. However, eight fractions were detected for salivary proteins, that were identified as Alb, pre- $\alpha_{1}-\mathrm{G}, \alpha_{1}-\mathrm{G}, \alpha_{2}-\mathrm{G}$, $\beta_{1}-G, \beta_{2}-G$, IgA and $\gamma$-G. In all saliva samples, clear peaks were observed for the $\operatorname{IgA}$ and Alb fractions, and the peak of $\operatorname{IgA}$ fraction was higher than that of Alb fraction (Fig. 4). Among the 8 fractions, the percentage area obtained by densitometry was

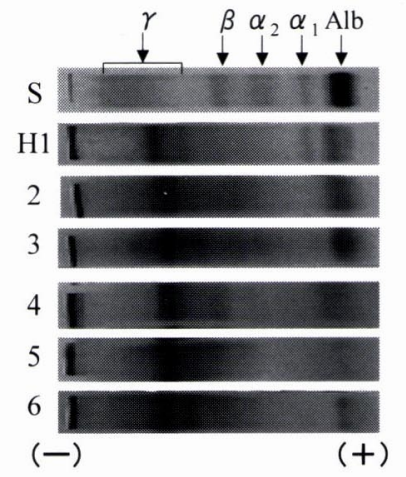

(a)

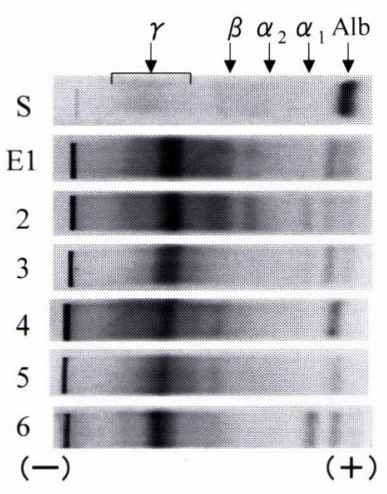

(b)
Fig. 3 Results of electrophoresis of salivary protein. (a) Dentulous subjects, (b) Edentulous subjects. S: Electrophoresis Control for Serum Protein $(400 \mathrm{mg} / \mathrm{l}), \mathrm{H} 1-6$ : Dentulous subjects, E1-6: Edentulous subjects

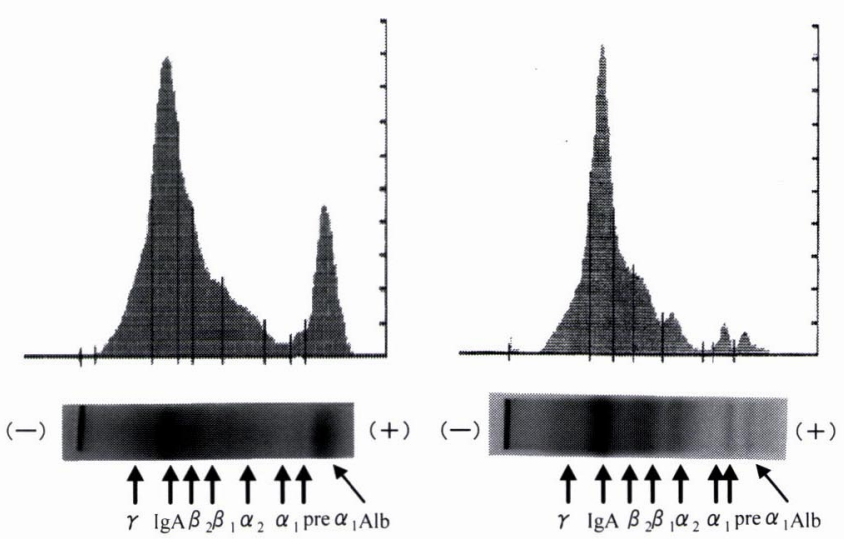

(a)

(b)

Fig. 4 Results of electrophoresis and densitometry curve of salivary protein. (a) Dentulous subjects, (b) Edentulous subjects

Table 2 The concentration percentage of salivary protein in saliva of dentulous subjects.

\begin{tabular}{|c|c|c|c|c|c|c|}
\hline \multirow{2}{*}{$\begin{array}{c}\text { Protein } \\
\text { fraction }\end{array}$} & \multicolumn{2}{|c|}{ Male } & \multicolumn{2}{c|}{ Female } & \multicolumn{2}{c|}{ Total } \\
\cline { 2 - 7 } & Number & $\%$ & Number & $\%$ & Number & $\%$ \\
\hline Alb & 26 & $10.9 \pm 4.4$ & 26 & $12.7 \pm 4.2$ & 52 & $11.8 \pm 4.4$ \\
\hline Pre $\alpha_{1}$ & 11 & $1.0 \pm 0.5$ & 5 & $1.6 \pm 1.1$ & 16 & $1.2 \pm 0.8$ \\
\hline$\alpha_{1}$ & 26 & $0.9 \pm 1.3$ & 26 & $1.2 \pm 1.1$ & 52 & $1.0 \pm 1.2$ \\
\hline$\alpha_{2}$ & 26 & $6.3 \pm 3.4$ & 26 & $7.1 \pm 3.4$ & 52 & $6.7 \pm 3.4$ \\
\hline$\beta_{1}$ & 26 & $13.5 \pm 2.6$ & 26 & $14.1 \pm 2.3$ & 52 & $13.8 \pm 2.5$ \\
\hline$\beta_{2}$ & 26 & $15.1 \pm 4.2$ & 26 & $14.7 \pm 3.1$ & 52 & $14.9 \pm 3.7$ \\
\hline $\operatorname{IgA}$ & 26 & $38.1 \pm 6.3$ & 26 & $35.2 \pm 4.5$ & 52 & $36.7 \pm 5.6$ \\
\hline$\gamma$ & 26 & $14.9 \pm 3.1$ & 26 & $14.7 \pm 4.1$ & 52 & $14.8 \pm 3.6$ \\
\hline & & & & \multicolumn{4}{c}{ (mean \pm 1 SD) } \\
\hline
\end{tabular}

largest for the $\operatorname{IgA}$ fraction (Table 2) whose mean value was $36.7 \pm$ $5.6 \%$ for the group of dentulous subjects and $39.0 \pm 4.6 \%$ for the group of edentulous subjects. In the group of dentulous subjects, the $\beta_{2}-\mathrm{G}$ fraction showed the next largest percentage area, $14.9 \pm$ $3.7 \%$, followed by $\gamma-\mathrm{G} 14.8 \pm 3.6 \%, \beta_{1} \mathrm{G} 13.8 \pm 2.5 \%$, and $\mathrm{Alb}$ $11.8 \pm 4.4 \%$. In the group of edentulous subjects, the percentage area of $\gamma-\mathrm{G}$ fraction was $19.1 \pm 4.3 \%$, followed by $\beta_{2}-\mathrm{G} 15.5 \pm$ $2.1 \%, \beta_{1}-\mathrm{G} 10.7 \pm 2.3 \%$ and Alb $7.0 \pm 2.8 \%$.

The concentration of individual protein fractions obtained by 
Table 3 The concentration of each salivary protein in saliva of dentulous subjects.

\begin{tabular}{|c|c|c|c|c|c|c|}
\hline \multirow{2}{*}{$\begin{array}{c}\text { Protein } \\
\text { fraction }\end{array}$} & \multicolumn{2}{|c|}{ Male } & \multicolumn{2}{c|}{ Female } & \multicolumn{2}{c|}{ Total } \\
\cline { 2 - 7 } & Number & $\mathrm{mg} / l$ & Number & $\mathrm{mg} / l$ & Number & $\mathrm{mg} / l$ \\
\hline Alb & 26 & $145.7 \pm 114.3$ & 26 & $144.2 \pm 114.2$ & 52 & $145.0 \pm 113.1$ \\
\hline Pre $\alpha_{1}$ & 11 & $14.4 \pm 14.9$ & 5 & $20.0 \pm 18.4$ & 16 & $16.1 \pm 15.7$ \\
\hline$\alpha_{1}$ & 26 & $10.4 \pm 11.2$ & 26 & $11.9 \pm 11.7$ & 52 & $11.1 \pm 11.4$ \\
\hline$\alpha_{2}$ & 26 & $78.9 \pm 61.2$ & 26 & $70.6 \pm 38.7$ & 52 & $74.7 \pm 50.8$ \\
\hline$\beta_{1}$ & 26 & $167.7 \pm 101.6$ & 26 & $157.0 \pm 95.1$ & 52 & $162.3 \pm 97.6$ \\
\hline$\beta_{2}$ & 26 & $187.2 \pm 116.9$ & 26 & $165.2 \pm 104.8$ & 52 & $176.2 \pm 110.4$ \\
\hline $\mathrm{IgA}$ & 26 & $486.2 \pm 276.3$ & 26 & $414.5 \pm 282.6$ & 52 & $450.3 \pm 279.0$ \\
\hline$\gamma$ & 26 & $181.2 \pm 97.1$ & 26 & $165.7 \pm 120.3$ & 52 & $173.5 \pm 108.6$ \\
\hline
\end{tabular}

$($ mean $\pm 1 \mathrm{SD})$

Table 4 The concentration percentage of each salivary protein of dentulous and edentulous subjects.

\begin{tabular}{|c|c|c|c|c|c|}
\hline \multirow{2}{*}{$\begin{array}{c}\text { Protein } \\
\text { fraction }\end{array}$} & \multicolumn{2}{|c|}{ Dentulous subjects } & \multicolumn{2}{c|}{ Edentulous subjects } & $p$ \\
\cline { 2 - 6 } & Number & $\%$ & Number & $\%$ & \\
\hline Alb & 52 & $11.8 \pm 4.4$ & 11 & $7.0 \pm 2.8$ & $p<0.01$ \\
\hline Pre $\alpha_{1}$ & 16 & $1.2 \pm 0.8$ & 10 & $2.3 \pm 3.1$ & n.s \\
\hline$\alpha_{1}$ & 52 & $1.0 \pm 1.2$ & 11 & $1.1 \pm 1.1$ & n.s \\
\hline$\alpha_{2}$ & 52 & $6.7 \pm 3.4$ & 11 & $5.5 \pm 3.2$ & n.s \\
\hline$\beta_{1}$ & 52 & $13.8 \pm 2.5$ & 11 & $10.7 \pm 2.3$ & $p<0.01$ \\
\hline$\beta_{2}$ & 52 & $14.9 \pm 3.7$ & 11 & $15.5 \pm 2.1$ & n.s \\
\hline IgA & 52 & $36.7 \pm 5.6$ & 11 & $39.0 \pm 4.6$ & n.s \\
\hline$\gamma$ & 52 & $14.8 \pm 3.6$ & 11 & $19.1 \pm 4.3$ & $p<0.01$ \\
\hline
\end{tabular}

$($ mean $\pm 1 \mathrm{SD})$

n.s: not significant

$p$ : healthy subjects vs. edentulous subjects

multiplying the percentage are to the total protein concentration was largest for the IgA fraction in a manner similar to the percentage area (Table 3), which was $450.3 \pm 279.0 \mathrm{mg} / \mathrm{l}$ for the group of dentulous subjects and $851.8 \pm 608.2 \mathrm{mg} / \mathrm{l}$ for the group of edentulous subjects. In the group of dentulous subjects, the next highest was $\beta_{2}-\mathrm{G} 176.2 \pm 110.4 \mathrm{mg} / \mathrm{l}$, followed by $\gamma-\mathrm{G} 173.5 \pm 108.6 \mathrm{mg} / l$, $\beta_{1}-\mathrm{G} 162.3 \pm 97.6 \mathrm{mg} / \mathrm{l}$ and Alb $145.0 \pm 113.1 \mathrm{mg} / \mathrm{l}$. In the group of edentulous subjects, the next highest was $\gamma-\mathrm{G} 457.3 \pm 435.6 \mathrm{mg} / l$, $\beta_{2}-\mathrm{G} 342.6 \pm 272.4 \mathrm{mg} / \mathrm{l}, \beta_{1}-\mathrm{G} 218.7 \pm 124.7 \mathrm{mg} / \mathrm{l}$ and Alb $151.8 \pm$ $133.1 \mathrm{mg} / \mathrm{l}$. No sex differences were observed in the percentage area and concentration of any protein fraction in either subject group.

The percentage areas of Alb and $\beta_{1}-\mathrm{G}$ fractions were significantly greater in the group of dentulous subjects $(p<0.01)$, whereas the percentage area of $\gamma-\mathrm{G}$ fraction was significantly greater in the group of edentulous subjects $(p<0.01)$. In addition, the concentrations of $\operatorname{IgA}$ and $\gamma-\mathrm{G}$ were significantly higher in the group of edentulous subjects $(p<0.05)$.

\section{DISCUSSION}

Total protein concentrations and protein fraction patterns in whole saliva could be obtained easily and clearly in the present study.

As a whole, individual differences were observed in protein concentration, but no sex difference was noted. Any one of 8 protein fractions showed no sex difference when they were expressed
Table 5 The concentration of each salivary protein of dentulous and edentulous subjects.

\begin{tabular}{|c|c|c|c|c|c|}
\hline \multirow{2}{*}{$\begin{array}{c}\text { Protein } \\
\text { fraction }\end{array}$} & \multicolumn{2}{|c|}{ Dentulous subjects } & \multicolumn{2}{c|}{ Edentulous subjects } & $p$ \\
\cline { 2 - 6 } & Number & $\mathrm{mg} / l$ & Number & $\mathrm{mg} / l$ & \\
\hline Alb & 52 & $145.0 \pm 113.1$ & 11 & $151.8 \pm 133.1$ & n.s \\
\hline Pre $\alpha_{1}$ & 16 & $16.1 \pm 15.7$ & 10 & $42.9 \pm 55.0$ & n.s \\
\hline$\alpha_{1}$ & 52 & $11.1 \pm 11.4$ & 11 & $29.1 \pm 52.1$ & n.s \\
\hline$\alpha_{2}$ & 52 & $74.7 \pm 50.8$ & 11 & $111.6 \pm 88.9$ & n.s \\
\hline$\beta_{1}$ & 52 & $162.3 \pm 97.6$ & 11 & $218.7 \pm 124.7$ & n.s \\
\hline$\beta_{2}$ & 52 & $176.2 \pm 110.4$ & 11 & $342.6 \pm 272.4$ & n.s \\
\hline IgA & 52 & $450.3 \pm 279.0$ & 11 & $851.8 \pm 608.2$ & $p<0.05$ \\
\hline$\gamma$ & 52 & $173.5 \pm 108.6$ & 11 & $457.3 \pm 435.6$ & $p<0.05$ \\
\hline
\end{tabular}

n.s: not significant

(mean $\pm 1 \mathrm{SD})$

$p$ : healthy subjects vs. edentulous subjects

in terms of either percentage area or $\mathrm{mg} / \mathrm{l}$.

Interestingly, the percentage areas of $\operatorname{IgA}$ and $\mathrm{Alb}$ were relatively invariable in many saliva specimens, and the ratio of IgA:Alb was $3.8: 1(3.80 \pm 2.4)$ for the group of dentulous subjects and $7.0: 1(7.03 \pm 4.3)$ for the group of edentulous subjects. These IgA/Alb-ratios were significantly different from each other $(p<0.05)$. This is the interesting finding indicating that the IgA/Alb-ratio is constant even if the concentrations of salivary proteins are different among individuals.

The concentration of individual salivary proteins was higher in edentulous subjects than in dentulous subjects, though the age difference, $25.0 \pm 2.0$ years (dentulous subjects) vs. 78.8 \pm 8.1 years (edentulous subjects), must be taken into account. It is impossible, however, to make comparison only using elderly subjects, because aged persons rarely have healthy periodontium. With aging, parenchymal organs become atrophic and fatted, and the intracellular fluid accordingly decreases from 42 to $33 \%$. The water content per body weight is 60 to $70 \%$ in the adult, which decreases to 50 to $60 \%$ in the elderly because of aging-related deterioration of renal function. ${ }^{[15]}$ As a consequence, the ratio of the body fluid to the body weight decreases to raise the plasma osmotic pressure. ${ }^{[16]}$ In addition, the sensitivity to feeling dryness declines in the elderly due to the deterioration of individual sensory functions. Many elderly persons have basal diseases and are using certain drugs possibly inducing adverse reactions. Therefore, the elderly is liable to fall into a state of dehydration. Since water occupies $99 \%$ of saliva, stomatic dryness is induced easily 
by failed homeostasis of body fluids, drugs, pathogenic causes ${ }^{[17]}$ and morphological change in salivary glands. ${ }^{[18]}$ Although there are several previous reports on aging-related changes in the secretion of saliva, no unified concept is available yet. Such previous reports include the findings that the resting- and stimulated-secretion of submandibular saliva is decreased by about $22 \%$ and about $39 \%$, respectively, in the elderly, and that either resting- or stimulated-secretion of whole saliva and the secretion of parotid saliva are all decreased (but not significantly) in the elderly. However, the current concept which is most widely accepted is that restingsecretion of saliva is related with aging, whereas the stimulatedsecretion of saliva is unrelated with aging. ${ }^{[19]-[21]}$

Various results are reported also on the concentration of salivary proteins, including that the protein concentration of whole saliva is 20 to $30 \mathrm{mg} / \mathrm{l}$ higher in the elderly but this is not statistically significant. ${ }^{[21]}$ Thus, it is still difficult to find consistency in total protein concentration in the elderly in whom the number of residual teeth and the condition of periodontal tissues are not uniform and not a few systemic diseases are present. However, it may be said based on the results of the present study and the features of the elderly mentioned above that the salivary protein concentration is high in the edentulous subjects who are not affected by the number of residual teeth and the condition of periodontal tissues.

Regarding individual protein fractions, the percentage areas of Alb and $\beta_{1}-\mathrm{G}$ fractions were significantly greater in dentulous subjects, whereas the percentage area of $\gamma-G$ was significantly greater in edentulous subjects. The saliva is the low tension fluid produced and secreted by the following processes: Plasma constituents are taken up into acinar cells through capillary walls and tissue fluids, and the substances synthesized in acinar cells are liberated into acinous cavities together with water through the secretion or re-uptake of water or electrolyte ions at various ductal cells. ${ }^{[6]}$ Salivary proteins are originated mainly at salivary glands and at exudates from the gingival sulcus in dentulous subjects and at salivary glands in edentulous subjects. In any case, salivary proteins are plasma proteins originally, and it is thus highly possible that changes in plasma constituents are reflected in saliva. Serologically, the blood Alb level tends to decrease due to agingrelated insufficient ingestion of nutrients and to chronic disorders. ${ }^{[22]}$ Salivary Alb is originated at the submandibular and sublingual glands in addition to exudates from the gingival sulcus. Among three major salivary glands, the submandibular gland is most largely affected by aging, and the number of acinar cells in submandibular gland declined by $60 \%$ or more with aging. The parotid and sublingual glands also have similar tendencies but not so markedly as the submandibular gland. ${ }^{[14]}$ For the reasons mentioned above, it is conceivable that the ratio of Alb fraction is low in edentulous subjects, because Alb is originated only at the salivary gland.

Immunoglobulins in blood are liable to increase with aging for the following reasons: With aging, the bone marrow becomes the main site of antibody production, plasma cells increase, $T$ cells and $\mathrm{B}$ cells decrease, the immunosuppressive function due to $\mathrm{T}$ cells declines, the secondary antibodies produced against numerous antigens accumulate, and the mechanism of immune system gradually destroys. Among immunoglobulin-producing cells, those producing IgA and IgG tend to increase particularly, and, as a consequence, the serum levels of IgA and IgG elevate. ${ }^{[23]}$ Salivary IgA is locally produced at salivary glands, the parotid gland in particular, and the parotid gland is barely affected by aging. For these reasons, concentrations of IgA and $\gamma-\mathrm{G}$ in terms of $\mathrm{mg} / \mathrm{l}$ were significantly higher in edentulous subjects than in dentulous subjects. The significantly high levels of $\gamma-\mathrm{G}$ fraction in edentulous subjects are thought to largely reflect changes in blood constituents in these subjects. But, it is hard to separate clearly IgG and $\operatorname{IgA}$ fractions on this electrophoresis, increased salivary $\operatorname{IgA}$ level may affect the change of $\gamma-\mathrm{G}$ fraction.

\section{CONCLUSIONS}

In the present study, it was possible to demonstrate differences between dentủlous subjects and edentulous subjects owing to the establishment of the total protein concentration in whole saliva and the standard value of individual salivary proteins in dentulous subjects, and also owing to comparison with edentulous subjects. In particular, it was found that the total protein concentration and the IgA/Alb-ratio were higher in edentulous subjects. Since it was suggested that the saliva was largely affected by aging, the presence or absence of teeth, and stomatic and systemic conditions, it is thought necessary to analyze further the concentration and composition of salivary proteins under various morbid conditions.

\section{REFERENCES}

[1] Dowd, F.J.: Saliva and Dental Caries, Dent Clin North Am, 43(4): 579-597, 1999

[2] Kaufman, E., Lamster, I.B.: Analysis of Saliva for Periodontal Diagnosis, A Review, J Clin Periodontol, 27: 453-465, 2000

[3] Shiba, A., Shiba, K., Suzuki, K.: Analysis of Salivary Proteins by Thin Layer Sodium Dodecylsulphate Polyacrylamide Gel Electrophoresis, J Ora Rehabil, 13: 263-271, 1986

[4] Bandai, M., Okuyama, H., Katayama, S., Shiba, A.: Viscosity of Saliva in Relation to Denture Retention. Part 2. Viscosity of Mediating Fluid in Relation to Retention of Denture, Nippon Hotetsu Shika Gakkai Zasshi, 31(4): 837-843, 1987

[5] Shiba, A., Yoshida, J.: Denture Base Retention and Palatine Gland Saliva, Kokubyo Gakkai Zasshi, 39(3): 470-488, 1972

[6] Sue, P., Humphrey, R.D.H., MSEd, Russell, T., Williamson, D.M.D.: A Review of Saliva. Normal Composition, Flow, and Function, J Prosthet Dent, 85: 162-169, 2001

[7] Edgar, W.M.: Saliva: Its Secretion, Composition and Functions, $\mathrm{Br}$ Dent J, 172: 305-312, 1992

[8] Heintze, U., Frostell, F., Trell, E.: Secretion Rate and Buffer Effect of Resting and Stimulated Whole saliva in Relation to General Health, Swed Dent J, 10: 213, 1986

[9] Descos, L., Lambert, R., Minaire, Y.: Comparison of Human Salivary Secretion in Health and Chronic Pancreatitis, Digestion, 9: 76, 1973

[10] Dobrilla, G., Valentini, M., Fillipini, M., Bonoldi, M., Felder, M.C., Moroder, E., Schnabl, D., Gaspa, U.: Study of Parotid and Mixed Saliva in the Diagnosis of Chronic Pancreatitis, Digestion, 19: 180,1979

[11] Le Bell, Y., Soderling, E., Kirveskari, P., Alanen, P.: Flow Rate, $\mathrm{pH}$ and Buffer Capacity of Whole Saliva Before and After Treatment of TMJ Drysfunction, Proc Finn Dent Soc, 81: 226, 1985

[12] Henskens, Y.M.C., Van der Velden, U., Veerman, E.C.I., Nieuw Amerongen, A.V.: Protein, Albumin and Cystatin Concentrations in Saliva of Healthy Subjects and of Patients with Gingivitis or Periodontitis, J Periodont Res, 28: 43-48, 1993

[13] Matsuda, K., Hiratsuka, N., Koyama, T., Kurihara, Y., Hotta, O., Itoh, Y., Shiba, K.: Sensitivi Meyhod for Detection and Semiquantification of Bence Jones Protein by Cellulose Acetate Membrane Electrophoresis Using Colloidal Silver Staining, Clin Chem, 47: 763-766, 2001

[14] Matsuda, K., Hiratsuka, N., Kurihara, Y., Shiba, K.: A Semiquanti- 
tative Analysis of Urinary Low Protein Levels Using Silver dot Blot Assay: J Clin Lab Anal, 15(4): 171-174, 2001

[15] Goldman, R.: Speculations on Vascular Chages with Age, J Am Geriat Soc, 18: 766, 1970

[16] Mack, G.W., Weseman, C.A., Langhans, G.W., Scherzer, H., Gillen, C.M., Nadel, E.R.: Body Fluid Balance in Dehydrated Healthy Older Men. Thirst and Renal Osmoregulation, J Appl Physiol, 76: 1615-1623, 1994

[17] Sreebny, L.E., Steven, S.S.: Reference Guide to Drugs and Dry Mouth, Gerodontology, 5: 75-99, 1986

[18] Ida, M., Honda E.: Age-dependent Decrease in the Computed Tomographic Numbers of Parotid and Submandibular Salivary Glands, Dentomaxillofac Radiol, 18: 31-35, 1989

[19] Helf, M.W., Baum, B.J.: Unstimulated and Stimurated Parotid Salivary Flow Rate in Individuals of Different ages, J Dent Res,
63: 1182-1185, 1984

[20] Pedersen, W., Schuberyt, M., Lzutsu, K., Mersai, T., Truelove, E.: Age-dependent Decrease in Human Submandibular Gland flow Rates as Measured Under Resting and Post-stimulation Condition, J Dent Res, 64: 822-825, 1985

[21] Ben-Aryeh, H., Shalev, A., Szargel, R., Laor, A., Laufer, D., Gutman, D.: The Salivary Flow Fate and Composition of Whole and Resting Stimulated Saliva in Young and Old Healthy Subjects, Biochem Med Metab Biol, 36: 260-265, 1986

[22] Denko, C.W., Gabriel, P.: Age and Sex Related Levels of Albumin, Ceruloplasmin, Alpha 1 Antitrypsin, Alpha 1 Acid Glycoprotein, and Transferring, Ann Clin Lab Sci, 11(1): 63-68, 1981

[23] Stak, W., Szczepanik, M.: Immunogerontology-aging of the Immune System and Its Cause, Przegl Lek, 55(7-8): 397-399, 1998 